\title{
"THAT I COULD LOOK . . . ON MY OWN CRUCIFIXION AND BLOODY CROWNING": WALT WHITMAN'S ANTI-GALLOWS WRITING AND THE APPEAL TO CHRISTIAN SYMPATHY
}

\author{
Paul Christian Jones
}

Walt Whitman's involvement in the anti-capital punishment movement, primarily as a journalist in the 1840 s, has never been properly understood by scholars of his work nor has it been recognized as having significant relevance to understanding his later work, the poetry of Leaves of Grass. If acknowledged at all, it is often treated as a youthful phase, in which the twenty-something Brooklyn newspaperman was caught up in the latest reform fad. ${ }^{1}$ In this essay, I argue that scholars have been mistaken to ignore Whitman's early commitment to antigallows reform, as I explore his participation in the movement, tracing his efforts from his impassioned anti-gallows editorials for various periodicals to his transference of these expressions into his verse. ${ }^{2}$ Sharing Michael Moon's assumption in Disseminating Whitman that Whitman saw no distinction between his political and literary writing and "insisted on the interconnectedness of these realms," 3 this essay illustrates that an understanding of Whitman's strong political commitment to the abolition of the death penalty can inform our reading of the poetry in Leaves of Grass, especially in terms of his arguments for sympathy for condemned criminals and his use of the rhetoric of "Christian sympathy," a rhetoric very common in antebellum anti-gallows arguments. This essay will demonstrate that a reader's knowledge of Whitman's interest in this rhetoric can elucidate famous passages of Whitman's verse, including sections of "Song of Myself."

Whitman's advocacy for the abolition of capital punishment began in his youth. As a 19-year-old member of the Smithtown [New York] Debating Society, Whitman argued in favor of abolition when the question up for debate was "Ought capital punishment to be abolished?" When he became a professional journalist, the subject of the death penalty appeared frequently in his articles, sometimes merely in the form of reportage (the coverage of a trial or a hanging) but more often in the form of an editorial making a case for the necessity of ending 
capital punishment. His journalistic career began when the discussion about abolishing the gallows was reaching its height in New York, as the Democratic Review waged its campaign against hanging, as state and local societies sprang up in support of the reform, and as anti-death penalty meetings, petitions, and pamphlets were ubiquitous. ${ }^{5}$ Even though Whitman was writing anti-gallows pieces for various publications, including the Democratic Review, it was when he assumed the editorial helm of the Brooklyn Daily Eagle in 1846 that he held his most influential role in the anti-gallows movement, publishing dozens of his own pieces advocating the abolition of hanging as well as those by like-minded writers. In his editorials, he referred readers to other anti-gallows publications, advocated a more active Brooklyn society in support of abolition of the death penalty, and, in 1847, even scolded the Review for what he saw as its declining commitment to this issue. Because of this activity, Thomas Brasher, in his study of Whitman's editorship of the Eagle, characterizes Whitman as being "by himself . . . a kind of society for the abolition of capital punishment" (Brasher, 151).

In a recollection of the movement, written for the Brooklyn Times in 1858, Whitman fondly remembered his activism and pronounced the product of the movement as worthwhile. Even though capital punishment had not been abolished, Whitman asserted that reformers did achieve "an increased sensitiveness on the part of the public, toward any useless harshness in the treatment of criminals" and "diffus[ed] more benevolence and sympathy through the public mind, elevating the range of temper and feeling, and reacting in a hundred different modes, indirectly upon the popular taste, and upon criminal law, the doings of Courts and Juries, and the management of Prisons." In the effects Whitman describes, "increased sensitiveness" and "more benevolence and sympathy through the public mind," we find his articulation of the intended aim of all of his anti-gallows writing, from the earliest journalism of the 1840s to the mature poems of Leaves of Grass, where Whitman continued to challenge the gallows and work to produce sensitivity and understanding on the part of the reading public towards society's criminals; in all this work he argues for a sympathetic response that would lead his readers to oppose the death penalty as ineffective, inhumane, and immoral.

\section{Whitman's Anti-Gallows Fournalism and the Appeal to Sympathy}

For Whitman, a newspaper had a purpose larger than merely informing its readership of current events. In an 1846 editorial, he explained, "much good can always be done, with such potent influence as a well circulated newspaper. To wield that influence is a great 
responsibility. There are numerous noble reforms that have yet to be pressed upon the world. People are to be schooled, in opposition perhaps to their long established ways of thought."7 Thus, Whitman considered journalism, at its best, to be a form of progressive activism, and the abolition of capital punishment was one of the foremost of the "noble reforms" that he pursued in this "schooling" of his newspaper readership of the 1840 s.

His earliest known newspaper pieces on the subject appeared in November 1842, the period when the infamous murderer John C. Colt was awaiting execution. His editorials of this time echo much of the rhetoric against the gallows appearing in the Democratic Review and other anti-gallows publications. The first article, "Capital Punishment and Social Responsibility," sought to persuade its readers that all members of society are "directly responsible for wrong, oppressive, inhuman, cruel and tyrannical laws." After failed attempts to abolish capital punishment in the New York State Legislature in 1841 and 1842, Whitman believed that society had "lull[ed] the sensitive conscience into a delusive slumber" from which he wanted to awaken his readers, to show them the influence they could exert on their legislators and thus on the continued use of hanging. Like other anti-gallows activists, Whitman directed his strongest criticism at the clergy, who were often the death penalty's strongest supporters or at least complicit, according to Whitman, for their failure to denounce the practice:

Why is the pulpit silent on this all-absorbing topic? While judicial murder is executed on a human soul, why do the clergy seem idle accessories and indifferent spectators? Do they feel no moral responsibility moving upon their consciences to exhort a reformation in their cruel superstition? . . . [T] his tacit consent is . . . an unpardonable neglect of duty. One would think their anxiety for their holy cause, and an overruling desire to prove to the world, that the Redeemer had not died in vain to soften that depravity of the human heart of which they preach, would be sufficient stimulus to impel them to the work. (Fourn, 1:160-161)

In this, his earliest known piece against capital punishment, Whitman already implies what will grow to be a major point in his argument against capital punishement: that the practice of the death penalty is antithetical to Christianity and that the clergy, who either were its supporters or who chose not to preach against it, were failing in their Christian mission.

Over the course of the 1840 s, Whitman returned to the subject of the gallows in dozens of pieces, most of them written for the Eagle when he was crime reporter as well as editor from 1846 to 1848 . Crime reporting in the 1840s, as David Papke has argued, was becoming increasingly politicized. ${ }^{8}$ For example, Papke explains that journalists 
might use their descriptions of criminal proceedings to defend the working class who were frequently mistreated by the justice system or to condemn the police and courts when they were easily manipulated by the wealthy and powerful. As we have seen in the piece discussed above, Whitman's crime reporting was likewise politicized, as he consistently used his coverage of crime to present the by-then standard arguments against the death penalty circulating in the 1840 s. These arguments included that there was the possibility of convicting and executing innocent people; that capital punishment did not serve as a deterrent; that the spectacle of hanging actually encouraged dangerous and criminal behavior in the populace, including homicide, domestic and animal abuse, and suicide; that teaching the preciousness of life by executing someone seemed counterintuitive; and that juries had begun to refuse to convict criminals, out of fear that they would be sentenced to death, and thus, actual guilty people were going unpunished and set free because of the existence of the death penalty. ${ }^{9}$

Despite the various logical arguments that Whitman makes against hanging, the dominant appeal that Whitman makes in these writings is an emotional rather than a rational one. That is, he often asks his readers to feel for the criminals he is writing about, to identify sympathetically with them, and to imagine themselves in the place of these criminals. His embrace of this approach in his journalism anticipates those famous sympathetic proclamations of his poetry, such as his persona's description of himself in "Song of Myself" as "I am he attesting sympathy" (LGVar., 1:28) and his assertion that "I do not ask the wounded person how he feels, I myself become the wounded person" (52). ${ }^{10}$ For example, in one piece where he advocates life imprisonment rather than execution for convicts, he observes: "Looking only at the criminal in connection with the great outrage through which we know him, we forget that he is still a duplicate of the humanity that stays in us all. He may be seared in vice, but if we could stand invisible by him in prison and look into his soul, how often during those terrible nights might we not see agony compared to which the pains of the slain are but a passing sigh!" (Fourn, 1:302). This acknowledgement of the humanity of the criminal, the awareness of his pain, and the move toward a sympathetic understanding of his plight are striking aspects of Whitman's writing about specific criminals as well. For example, in his commentary on the execution of Henry Wyatt, a convicted murderer in Auburn, New York, he portrays Wyatt as "a most abandoned young man" and asks the reader to "contemplate his nature-his furious physical passions, his early ignorance, depraved companionship, want of pure example, and the fatal fostering of the first seeds of sin in his breast till the roots became knit in his very life" (Fourn, 2:56). 
Perhaps the best illustration of how Whitman's sympathetic approach differed from the more typical journalistic handling can be seen through a comparison of his writing about a specific case, that of confessed murderer William Freeman, with the coverage provided by other contemporary reporters. Whitman discussed Freeman in the sarcastically titled 1846 piece, "Hurrah for Hanging!," written after Freeman, an African-American man, was convicted for the murder of five members of a family in rural New York. While the article begins by calling Freeman a "monster" and "the butcher of five human beings" and acknowledging the public appetite for his execution, Whitman asks his reader to consider the circumstances of this "neglected, ignorant and depraved negro" and "uneducated, friendless outcast," who "has never had the benefit of any kind of teaching or counsel; and never lived within any fixed moral or religious influences." Whitman asserts that Freeman's "whole character is of the most blindly brutal cast-a mere human animal." He then describes Freeman being convicted of horsetheft at age nineteen ("a crime of which he says he is not guilty") and being incarcerated in prison for five years, where "the idea of revenge [against the man who wrongly accused him] seems to have swallowed up all things else" and he became "blinded by his purpose of blood." Once released, he "not only strikes the object of his spite, the man who did him the supposed wrong, but . . . [also] plunges his knife into all whom he meets, sacrificing guilty and innocent alike." Whitman argues that the "very horror of the butchery" shows "how thoroughly diseased and confused the whole moral being of the murderer had become" (Fourn, 1:300-301). Whitman's response can ultimately be classed as sentimental, consistent with this approach's tendency, as Philip Fisher describes it, to experiment "with the extension of full and complete humanity to classes of figures from whom it has been socially withheld." Fisher notes that "the typical objects of sentimental compassion are the prisoner, the madman, the child, the very old, the animal, and the slave."11

"Hurrah for Hanging!" displays a plea for understanding of this mass murderer that is not seen in other contemporary coverage of Freeman's crime. For example, the National Police Gazette's coverage is devoid of compassion or understanding, noting that it "is difficult to attribute any sufficient motive to the monster for the commission of the deed." Calling Freeman a "wretch" and an "assassin," the Gazette narrates in gruesome detail the killing of each victim, including the child of "but two years old" who became the "object of his hellish vengeance." 12 In another piece on Freeman, the Gazette posits a potential motive, noting that a cousin of Freeman was also convicted for murder six years before: "there must be some bad blood running in the veins of 
the Freeman tribe. It is stated that Wm. Freeman is one-quarter Indian, his mother having been one-half Indian." ${ }^{13}$ However, this possibility of "bad blood" is not used by the Gazette to excuse the crime, but instead serves to make him only more alien and monstrous, rather than potentially sympathetic. Similarly, the account in the Harbinger eventually reaches a crescendo of gory melodrama: "Upon the floors-upon the snow - upon the steps - the doors-every where-blood, blood marked the murderer's tracks. What a night of horror was that." Even though the correspondent notes details similar to those Whitman relates, including the wrongful imprisonment, and claims to be "strongly opposed . . . to Capital Punishment," he argues nonetheless that "there cannot be the slightest sympathy for the culprit; a more cold-blooded, villainous butchery was probably never committed in this or any other age or country." 14 So while this piece acknowledges that the justice system has failed Freeman, it does not make the leap that Whitman makes: to assert that the primary responsibility for his horrendous crime should be placed not on the criminal himself but rather on the society that had brutalized him and the flawed justice system that had failed him.

Whitman understood that his appeal to sympathy for criminals, like Wyatt and Freeman, opened him up to criticism. He predicted in the Wyatt piece that the defenders of the gallows, whom he calls "conservator[s] of "justice," would condemn his characterization as "the fruit of "mawkish sympathy," and will find it "horrible and blasphemous, and dangerous to the land, to utter one word of sympathy and pity for him whom society has thrust out" (Fourn, 2:56). He knew that his handling of these cases placed him directly in the midst of the arguments about sympathy being waged in these years between defenders of the gallows and those advocating its abolition. As one would expect, writers defending the gallows, many of them Congregationalist and Presbyterian ministers, ridiculed the abolitionists' concern for the criminal as misguided and foolish. For example, Congregationalist minister Leonard Bacon agreed that citizens should have "a natural and reasonable sympathy" for the condemned, but cautioned against letting it go further: "If, in our sympathy, we forget the crime for which that suffering is inflicted-if, in our sympathy, we cry out against the wickedness of society in putting the poor fellow into prison and treating him so badly - our sympathy has grown excessive, unreasonable, morbid." ${ }^{15}$ Other ministers echoed these sentiments, like Congregationalist Joseph Thompson, who described compassion for the condemned as "weak sympathy for a guilty man."16 The most famously outspoken of the defenders of the gallows, New York Presbyterian minister George B. Cheever, described this feeling as the "false sentimentality and compassion that lead men to exercise a deeper sympathy with the murderer . . . than with the murdered man."17 
The voices of abolition, often ministers themselves, mounted a vigorous defense of their pleas for sympathy for the condemned. Universalist minister William Barber argued that society has an obligation to its criminals because "the murderer is a man who is morally diseased" and "we are as much bound to support him, as we are to support the sick and aged." 18 Universalist minister E. H. Chapin rejected the notion, asserted by the conservatives, that this sympathy is a "morbid feeling" and went even further to argue that this feeling is actually the key element to all social progress:

Morbid feeling! This has always been the cry. It was a morbid feeling in those who protested for the rights of individual conscience-it was a morbid feeling in our Puritan fathers that excited them to resist the tyranny of the Church. . . . It was a morbid feeling that introduced the patriots of the Revolution to rebel. It was a morbid feeling that softened down the harsh penalties of cutting out the heart, of transfixing the head on a pole and of stretching on a rack, to hanging on a gibbet. . . . And I expect that this morbid feeling will continue until the ermine of Justice shall be no longer stained with blood, until men learn to be merciful even while they punish, until they learn that the true policy of society is not severity but reformation. If all this-and it is all of a kind-is morbid feeling, let it work on. To me it looks like that energy tempered by reason and guided by Christianity that has led to all the beneficial and glorious reforms that have heretofore been accomplished. ${ }^{19}$

Like Chapin, other writers concurred that this sympathy was an essential part of Christianity. For example, Universalist minister Samuel Brimblecom argued that what is called "mawkish sensibility" is really "Christ within' that condemned the practice of killing." ${ }^{20}$ In his attack on capital punishment, the Universalist minister G. W. Quinby asserts that critics who call sympathy for criminals morbid "might as well charge CHRIST HIMSELF with cherishing a 'morbid sympathy.",21

Indeed, these anti-gallows activists often held up Christ as the model of how Christians should feel towards criminals and toward the practice of capital punishment. For example, an essay, signed J. M. M., urged this attitude toward the condemned:

Feel for him, then, as Christ would feel,-with an intense compassion. Restrain not your sympathies. Deal faithfully with his sins, condemn and avoid them; but cherish towards him no other emotions than pity for his misfortunes and sorrow for his guilt. Pray for his reformation. Encourage the faintest hope of recovery; and remember that if by your instrumentality a soul is saved from death, it will forever be your joy and crown of rejoicing. How often have we witnessed the beneficent influence of such a course of conduct towards the erring! . . . How many have been thrown back even into still worse habits of sin for want of Christian sympathy, counsel and assistance. ${ }^{22}$ 
Though his unorthodox religious views are not usually considered to be traditionally Christian, Whitman does explicitly embrace, in his journalism about capital punishment, this connection between Christianity and sympathy advocated by these reformers. ${ }^{23}$ In an 1846 editorial, for example, he challenged those "who see in all feeling for the wicked a "mawkish sympathy" by asking, "who are we to pity . . . if not those most pitiable of all our fellow creatures - the doers of great crimes?" He argues that "Christ's ministry was for them" and implores readers to "forget not that the same God who made us, made them - and that his sunshine and blessings come alike to them as to us. If it be 'mawkish sympathy' to think so, then was the Great Expiator of sin the weakest and wildest visionary of us all!" (Fourn, 1:258). In another response to the charge of "mawkish sympathy," Whitman points out that it is "quite fashionable, among a certain set of men, to denounce and turn up their noses at those who, following the spirit of Christ, would 'overcome evil with good,' and give not way to wrath and revenge." Yet, he notes that "some of this set of men get up of Sundays in the pulpit and hold forth as the accredited ministers of Him who was without guile," an act that he labels "Shameless perversion!" (Fourn, 2:44). ${ }^{24}$ In an 1847 article, he answers the charges that sympathy for executed criminals is mere "'sentimentality' - a foolish weakness, only fit for women and children," by contending that "nearly all that is good and pure in the world-in law, government, human action, and other departments of life-proceeds from the impulses of this 'sentimentality," which he attributes to "the divine emanation of CHRIST's purity and gentleness" (Fourn, 2:289). In these pieces then, readers can see that Whitman aligned himself with those antagonists of capital punishment who argued that sympathy was a necessary quality of being Christian. Whitman not only advocated such sympathy but displayed it in his anti-gallows journalism.

As Whitman encourages his newspaper audience to sympathize with the condemned, he implies that the same society and justice system that have failed the individuals in the headlines could just as easily fail any of his readers. Consequently, he does not hesitate to suggest that any human being could find him or herself, under the right circumstances, in the place of these murderers facing the gallows. In this move both to make his readers feel for the condemned and also to, in a sense, become the condemned (or at least to begin to equate the criminal with themselves), we see the work of the project of sympathetic identification. As Glenn Hendler explains, "To feel compassion, as opposed to mere pity, one must be able to imagine oneself, at least to some extent, in another's position." Hendler quotes Adam Smith's discussion of sympathy in The Theory of Moral Sentiments to justify his claim: "By the imagination we place ourselves in his situation, we conceive ourselves enduring all the 
same torments, we enter as it were into his body and become in some measure the same person with him." ${ }^{25}$ Sharing this understanding of sympathetic identification, Whitman equates himself and his reader with the criminals under discussion in his journalism. For example, in his coverage of the Colt case, he explains the lesson that his audience should draw from the tragic events:

That lesson teaches how frail and weak is poor human nature-how little we know ourselves - what strangers we are to our own evil propensities - how much we need the support of high, stern, and rock-founded moral principle-and how terrible and uncontrollable is the wild tempest of human passions when once they obtain the mastery over the reason and the conscience. (fourn, 1:162)

He asks his reader to reflect upon whether they would have been able to act differently than Colt: "Do we know ourselves any better than he knew himself? Do we comprehend, and have we the fixed moral principle, the high moral energy to control, the fearful volcano of human passions, whose maddened fires roar and blaze within our bosoms?" (Fourn, 1:163).

In his commentaries on these crimes, Whitman almost always serves as the mediator between his readers and these objects of sympathy, including Wyatt and Freeman; readers always hear his voice as he tries to reproduce within them his compassion for the condemned. However, he does allow one of these convicts to speak for himself in "A Dialogue," an 1845 piece published in the Democratic Review. This piece strays from being attached to the reporting of a contemporary crime and instead introduces a "fanciful dialogue" between society and a condemned criminal, to present almost every argument that could be garnered against the death penalty at the time. While all of the familiar anti-gallows arguments appear in "A Dialogue," Whitman devotes most of the piece to the convict's argument with members of society, one that asserts that they do not hold the moral high ground nor are they different from the criminal himself. As the convict proceeds through his dialogue, Whitman shifts his readers' sympathies. As readers begin this essay, they most naturally would view themselves as aligned with members of society (for that is what they are) rather than with this criminal (because they see no connection to this demonized figure). However, this alignment, as we shall see, does not hold up as the convict points a finger at society and the reader eventually joins him in the finger-pointing. Upon society's insistence that "we shall strangle you; your crime deserves it," the convict, a condemned murderer, asks them, "Have you, then, committed no crimes?" (Fourn, 1:205), directing both the society within the dialogue and its readers to examine themselves. The convict suggests that some of these individuals who 
make up society (and the readership as well) are guilty of crimes equal to, if not greater than, his own. His crime is that he struck a neighbor with a "heavy blow" when a "frenzy came over" him due to the "great passions" making up his "physical temperament." The voices of society admit that one of them had a mother who pined away and died because of his intemperance; another is a landlord who evicted a poor family from his building, leading to the death of two children; and yet another admits to having "effected the ruin of a young girl," who later drowned herself. Society concludes this confession of its crimes by asserting that "We are all frail!," an admission that causes the convict to plead with them "to sympathise with me-to let me not be hung" (206). Ultimately, this dialogue attempts to school its audience in a sympathetic response, as it manipulates the reader into identifying with the convict, modeling itself after Adam Smith's depiction of the sympathetic process as Whitman (and perhaps the reader) has entered into the body of the convict and "become in some measure the same person with him." The dialogue also anticipates Whitman's poetics, which, according to Karen Sánchez-Eppler, is "a poetics of merger" wherein the poet attempts to resolve differences with a "rhetoric of amalgamation." 26 This text then demonstrates the desired outcome of Whitman's project for his readers and encourages them to identify with, even "become," the convict who speaks so persuasively with Whitman's voice.

Highlighting the consequence of failing to practice this sympathy, Whitman casts his dialogue as a debate between an individual ("I") and society ("we"); all the voices other than the convict are combined into a corporate identity. While this "society" is made up of individuals, they do not think of themselves as such, nor do they even consider or argue from their own individual interests; instead they only voice the State's policies. In fact, because they cannot conceive of themselves as this convict or imagine themselves in his place, Whitman suggests they are able to condone violence against an individual that would otherwise be reprehensible. When the criminal claims that the very act of demanding his death (as "revenge" for the harm he has caused society) is as much of a crime as his own deed was, society differentiates between his acts and those of the State: “The case is different,' rejoins society. 'We are a community-you are but a single individual"' (Fourn, 1:206). The dialogue points out the irony that "that which is barbarous, false, or selfish for an individual becomes singularly proper when sanctioned by the legislature, or a supposed national policy" and that "deeds wicked in a man are thus applauded in a number of men" (208). Whitman here posits that if murder is an "awful crime" because it "invades the prerogative of God, for God's is the only power that can give life-and offers a horrid copy for the rest of mankind," then the "very facts which render murder a frightful crime, render hanging a frightful punishment" 
(208). He suggests that society's crime might even be worse than the convict's own since it is carried out with intention and forethought, unlike his own which was the act of passion.

In addition to attacking the defense of hanging as the privilege of the State, Whitman concludes by attacking the cloak of religion that is used to justify the death penalty. He characterizes the "founding . . . of the hanging system . . . on Holy Scriptures" as "a bold, impudent effrontery" and "a prostitution so foul of names and influences so awfully sacred" (Fourn, 1:208). He lists a number of "barbarous cruelties and martyrdoms inflicted in the name of God and his Sacred Word" (committed by the likes of Calvin, Henry VIII, Edward VI, and "Bloody Mary") and compares these historic atrocities to the current environment in which "clergymen call for sanguinary punishments in the name of the Gospel, - when, chased from point to point of human policy, they throw themselves on the supposed necessity of hanging in order to gratify and satisfy Heaven - when, instead of Christian mildness and love, they demand that our laws shall be pervaded by vindictiveness and violence." Whitman describes his soul as "filled with amazement, indignation and horror, utterly uncontrollable" at this perversion of religion and wonders if the Church's support for the gallows does not provide an obstacle to its Christian mission:

When I go by a church, I cannot help thinking whether its walls do not sometimes echo, "Strangle and kill in the name of God!" The grasp of a minister's hand, produces a kind of choking sensation; and by some optical fascination, the pulpit is often intercepted from my view by a ghastly gallows frame. . . . “O, Bible!" say I, "what follies and monstrous barbarities are defended in thy name!" (209)

This brief survey of Whitman's journalistic writing about the gallows shows him to be actively involved, as a writer, in this reform movement, following his notion that journalism should "press upon the world" such "noble reforms," through a process that he referred to as "schooling" his reader "in opposition . . . to their long established ways of thought" (Fourn, 1:392). One of the key elements in his education of the reader is teaching them to sympathize with the condemned, a process that attempts to create, as Kristin Boudreau explains, "a sympathetic identification" that would "replace difference with similarity" and allow the readers to "imagin[e] not what the spectacle must feel, but what the spectator himself would feel in the spectacle's place." ${ }^{27}$ As we see in "A Dialogue," Whitman also wants to remove social and cultural barriers that prevent the production of this sympathetic identification. As the ending of this essay makes clear, he viewed the Church's support for the death penalty to be one such barrier. His employment of the rhetoric of "Christian sympathy" is one of the ways he attempted 
to overcome this barrier, by arguing that, despite what the clergy might argue, sympathy for the condemned was not a sentimental weakness but a Christian imperative.

\section{"I am he attesting sympathy": Whitman's Poetics of Sympathy and the Case against Capital Punishment in Leaves of Grass}

Whitman's campaign against capital punishment was not confined to his prose. Indeed, one of his earliest poems, "Resurgemus" (published in 1850, later revised as "Europe, the $72^{\mathrm{d}}$ and $73^{\mathrm{d}}$ Years of These States" for inclusion in Leaves of Grass), echoes much of the anti-gallows rhetoric of the 1840s in which capital punishment was viewed as anti-democratic, a tool used by oppressive States to maintain control over their subjects. Another early poem, "Song of the Broad-Axe," also makes the argument that capital punishment has no place in a democratic society. As Whitman imagines America moving in the direction of becoming a "great city," he contrasts the American productive use of the axe with its less progressive employment in Europe by raising the issue of capital punishment in Section 8. The "European headsman," who "stands mask'd, clothed in red, with huge legs and strong naked arms," leaning upon "a ponderous axe," becomes the representative of Old World tyranny, which uses this axe as a tool of oppression and reactionary response to progress (LGVar., 1:184). Section 8 ends with Whitman's prediction that this use of the axe will eventually run its course:

I see the blood wash'd entirely away from the axe,

Both blade and helve are clean,

They spirt no more the blood of European nobles, they clasp no more the necks of queens.

I see the headsman withdraw and become useless,

I see the scaffold untrodden and mouldy, I see no longer any axe upon it,

I see the mighty and friendly emblem of the power of my own race, the newest, largest race. (185)

The use of the axe to kill criminals, he argues, is an obsolete remnant of Old World ways and certainly not part of the "great city" that he imagines. Yet, he acknowledges, in Section 10, that a version of this "headsman" does exist in America in the gallows, when he describes "the step-ladder for the convicted and sentenced murderer, the murderer with haggard face and pinion'd arms, / The sheriff at hand with his deputies, the silent and white-lipp'd crowd, the dangling of the rope" (187). Thus, America's full potential cannot be realized as long as capital punishment remains as a residual element of a past form of 
society, one that is tyrannical, afraid of progress, and unwilling to trust people to self-government.

Figures suffering the punishment of society, whether they are specifically referred to as murderers, felons, prisoners, or convicts, populate Whitman's poetry as he paints his all-encompassing portrait of America. Often, Whitman merely introduces these figures into his panoramic catalogues, alongside much more appealing characters, without any further comment or implicit argument against the gallows. For example, in Section 16 of "Song of Myself," which functions as an elaboration of the previous section's description of all the varied things that, Whitman's persona asserts, "more or less I am" (LGVar., 1:20), he concludes with this list: "A farmer, mechanic, artist, gentleman, sailor, quaker, / Prisoner, fancy-man, rowdy, lawyer, physician, priest" (21). While this type of insertion of convicted murderers and other criminals into Leaves of Grass serves as a strategy to provide an accurate picture of American life, other passages more explicitly attempt to humanize these figures and illustrate to readers that these criminals are essentially no different from themselves. For example, in "Salut au Monde!," as the speaker expansively salutes everything he sees in the world, he includes "prisoners in the prisons, / . . . The pirates, thieves, betrayers, murderers," and the speaker concludes by saying, "I go among them, I mix indiscriminately, / And I salute all the inhabitants of the earth" (LGVar., 1:172). The end of the next section of the poem strongly makes his point of equality among all: "Each of us [is] here as divinely as any is here" (174). This moment moves beyond an acknowledgement of the existence of murderers toward a more provocative argument asserting these murderers' equality to all other human beings.

Other poems continue Whitman's schooling of his audience in this lesson of leveling, finding more novel ways to equate the readers with figures to whom they might assume they are superior. "Song of the Open Road" uses the open road's acceptance of all human beings as a way to bring together the extremes of society, as it accepts "the felon, the diseas'd, the illiterate person" alongside more socially respectable figures, like the physician and the "laughing party of mechanics," as welcome on the road: "They pass, I also pass, any thing passes, none can be interdicted, / None but are accepted, none but shall be dear to me" (LGVar., 1:226-227). And, in "The Sleepers," Whitman makes a similar inclusion as he considers all the people on earth as they sleep, pondering " $[t]$ he murderer that is to be hung next day" and asking, "how does he sleep?" (110). In the poem, he also includes other similar figures: "[t]he criminal that stood in the box, the judge that sat and sentenced him, the fluent lawyers, the jury, the audience" (118). And 
he makes his equalizing agenda explicit as he notes: "I swear they [all the sleepers from every quarter of society] are averaged now-one is no better than the other, / The night and sleep have liken'd them and restored them. // I swear they are all beautiful" (118).

Like his journalism, his poetry eventually moved to produce sympathy in his readers for these criminals and condemned men, to get the readers to acknowledge the essential humanity that they share with these figures, and it sometimes turned to sentimentalism as a means of doing this. For example, "The Singer in the Prison," a poem inspired by a famous singer's performance for inmates in Sing Sing Prison, evokes sympathy for the prisoners by depicting their emotional response to the singer's moving hymn. The poem's singer, described only as "a lady" holding "a little innocent child by either hand," enters the room, crowded with hundreds of "sear-faced murderers," "thieves and outlaws of the land" who are gathered for "Sunday church in prison walls" and performs a "quaint old hymn" that is itself an expression of sympathy for their situation, as she imagines the pain of imprisoned souls:

A soul confined by bars and bands,

Cries, help! O help! and wrings her hands,

Blinded her eyes, bleeding her breast,

Nor pardon finds, nor balm of rest.

Ceaseless she paces to and fro,

O heart-sick days! O nights of woe!

Nor hand of friend, nor loving face.

Nor favor comes, nor word of grace.

It was not I that sinn'd the sin,

The ruthless body dragg'd me in;

Though long I strove courageously,

The body was too much for me.

Dear prison'd soul bear up a space,

For soon or late the certain grace;

To set thee free and bear thee home,

The heavenly pardoner death shall come. (LGVar., 3:598)

Her sympathetic address to the prisoners expresses an understanding of their circumstances - their "heart-sick days" and "nights of woe" without the encouraging "hand of friend" or "loving face" - and even places herself in their situation in a sense (the soul is a "she," and by the third stanza of the hymn she uses the pronouns "I" and "me" to discuss the soul's struggle against its "ruthless body"). After she asserts that death will be the "heavenly pardoner" that will free the soul from 
its prison, she ends the song with these two lines: "Convict no more, nor shame, nor dole! / Depart-a God-enfranchis'd soul!" (599), suggesting that God would see these men not as convicts but as souls.

The third section of the poem describes the effect of the singer's performance on the prisoners. As one would expect, given the sentimentality of the poem, their response is a tearful one: "While upon all, convicts and armed keepers ere they stirr'd, / (Convict forgetting prison, keeper his loaded pistol,) / A hush and pause fell down a wondrous minute, / With deep, half-stifled sobs and sound of bad men bow'd and moved to weeping" (LGVar., 3:599). The poem depicts within these lines the ultimate goal of Whitman's larger poetic project. The song's effect is felt by the convicts and their keepers, as both forget the elements that differentiate them. The vague word choice of line 44 as it describes "bad men" weeping, intriguingly could apply to both groups of men, especially if we accept the implication of the hymn that we all are slaves to our "ruthless" bodies. The tears are linked to the men's memories: "memories of home, / The mother's voice in lullaby, the sister's care, the happy childhood, / The long-pent spirit rous'd to reminiscence" (599). While the song and perhaps the maternal presence of its singer have this effect upon the men inside the poem, "The Singer in the Prison" is intended, of course, to affect the reader who perhaps needs to be reminded of the humanity of these "bad men," reminded that these murderers and thieves, like prison guards and the readers themselves, have mothers and sisters, that they were once children, and that they, too, feel. Most significantly, Whitman would want to impart to his readers, who probably see these men as a "[s] trange sea of prison faces," that they should see them instead as souls not very different from themselves.

Whitman intended his readers to put themselves into the place of these men and to imagine that they themselves could have come to similar ends if circumstances had been different. This project of leveling his readers with these social "inferiors" is made explicit in poems where Whitman's persona models this sympathetic identification with the criminal for his readers and asserts that the difference in circumstances between oneself and others is quite arbitrary. For example, in "You Felons on Trial in Courts," the speaker addresses the criminals of the world, including "convicts in prison-cells" and "sentenced assassins chain'd and handcuff'd with iron" and informs them that there is no reason that he is not being punished as they are, for he is just as "ruthless and devilish as any" (LGVar., 2:325). The 1860 version of the poem begins with an eight-line confession omitted from subsequent editions of Leaves, in which the persona announces, "I own that I have been sly, thievish, mean, a prevaricator, greedy, derelict, // And I own 
that I remain so yet" (325n). ${ }^{28} \mathrm{He}$ continues to confess, "What foul thought but I think it - or have in me the stuff out of which it is thought? / What in darkness in bed at night, alone or with a companion?" (325n). He acknowledges that the same elements that society condemns in the felons lurk unseen beneath the surface in himself. Though this specific confession disappears from subsequent versions, what remains is the implied guilt - a shared character trait between Whitman's speaker and the criminal element he addresses. Because he asserts that there is no difference in his own character and that of the criminal, he asks the felons, "Who am I too that I am not on trial or in prison? / . . . that my wrists are not chain'd with iron, or my ankles with iron?" (325). The first half of the poem insists that he is an equal to these figures whom society would deem his inferiors.

The second half of the poem turns from addressing the titular felons and instead addresses his reader, with this exclamation: "O culpable! I acknowledge-I exposé!" (LGVar., 2:325). The persona reveals the "foul thoughts" within: "Inside these breast-bones I lie smutch'd and choked, / Beneath this face that appears so impassive hell's tides continually run, / Lusts and wickedness are acceptable to me" (326). Because of this recognition of his own nature, he is able to embrace society's outcasts: "I walk with delinquents with passionate love" because "I feel I am of them-I belong to those convicts and prostitutes myself" (326). The product of this understanding of his own character and the equation of himself with the convicts is an ability to sympathize with them and to "walk with" them, a process that leads to an acknowledgement of obligation to them: "henceforth I will not deny them-for how can I deny myself?" (326). Notably, in this poem in which the persona ends with an assertion of a merging between "them" and "myself," a quite different dynamic than that portrayed in "A Dialogue," Whitman manages a clever, yet subtle, merging of his audience with the felons, shifting the "you" who is being addressed from the felons of the first six lines to his readers in the remainder of the poem, and, thus, "you" becomes a merged entity. This poem, like the song sung to the prisoners in "The Singer in the Prison," is addressed to social extremes with the purpose of uniting them in their common humanity, here exemplified in a shared sinful nature.

Recent literary scholars of nineteenth-century uses of sentimentalism and sympathy, like Marianne Noble, Elizabeth Barnes, and Kristin Boudreau, to name only a few, have been, according to Glenn Hendler, less interested in sympathy's "potential to build bridges between people" than "its colonizing proclivity to collapse them" (Hendler, 8). Even though Whitman explicitly employs sympathy to illustrate a common humanity between very different people, twentieth-century studies of 
Whitman's use of sympathetic identification have been more interested in the problematic consequences of such identification. These critics have examined the interaction between the poet and the objects of his sympathy, questioning both its motivations and its effectiveness. For example, although Denis Donoghue grants that Whitman's poetry can be read "as a hymn to the sympathetic imagination," he skeptically cautions that "it is one thing to suffer, and it is another thing to sympathize with the suffering of others, and these experiences are not identical, no matter what Whitman's equation says." 29 Numerous critics propose that the ends of Whitman's sympathy appear more self-interested than selfless. For instance, Stephen Black argues that Whitman's verse was more concerned with himself than the figures receiving his sympathy. Addressing the section of "Song of Myself" in which Whitman's speaker asserts, "I am the hounded slave" (LGVar., 1:51), Black claims that "the poet is more preoccupied with his own sympathies than with the slave . . . [, who] exists only as an idea by which the poet measures his humanity." ${ }^{30}$ Indeed, it has been Whitman's sympathetic handling of slave figures specifically that has proven the most controversial aspect in recent scholarship. For example, in Kristin Boudreau's examination of "Whitman's voracious sympathy for the slave," she wonders "what might become of the slave subjected to an unchecked sympathetic embrace" and posits that the consequence of Whitman's effort "to 'enter into' another is not to understand that other's feelings but to ensure that one's own be projected there" (Boudreau, 84-85).

While there is merit to what these critics say, it is useful here to remind ourselves how very different the terms and the central concerns of this scholarly discussion of sympathy are from those appearing in the debates about sympathy in the $1840 \mathrm{~s}$ and $50 \mathrm{~s}$. At that time, as we have seen already, the arguments are about who is a deserving object of sympathy and the consequences of that sympathy being misdirected or withheld. As noted earlier, many proponents of sympathy couched their arguments in terms of it being a Christian obligation, suggesting that "Christian Sympathy" could be both an alternative to capital punishment, as it would lead criminals to rehabilitation, but also a means to its abolition (that is, if people sincerely held this sympathy for criminals, they would never consent to executions). The most idealistic of these advocates, like Universalist minister E. H. Chapin, suggest that all social progress depended upon this practice. Chapin specifically asserts, "the great law of love, of Christian sympathy, must reign in your heart and mine, and then fraud and oppression and all sin will die for the face of the earth. All false institutions will crumble, having no support. And humanity will rise and shine in the splendor of a new day, and the beauty of a new power." He exhorted his readers: 
Let us, then, each in our sphere, go forth to cherish Christian sympathy, to feel a brother's wrongs as our own, to be as jealous of his rights as if ours were in peril. Not in wide results and in broad fields shall the work of human melioration be accomplished at first. But at our own doors, there may be sick, hungry, naked or in prison; some poor brother or sister may lie, needing some kindly word or friendly deed. How richly hath God blessed us with opportunities of imitating Him! A visit, a word, a smile, sometimes open a fountain of gladness in some worn and wasted heart, that will gush long years after, mingling with prayers for us. Thus, by cherishing the spirit of Christian sympathy, whenever he is brought in contact with wrong and suffering, a tide of sympathy shall flow out from heart to heart, that will finally meliorate the condition of our race. At least in ourselves will be a rich reward. By 'remembering those who are in bonds as bound with them,' our sleep will be none the less sweet, our sun will shine none the less pleasantly for it. ${ }^{31}$

Just as he did in his earlier journalistic writing, Whitman makes use of these assertions about the necessity and benefit of "Christian Sympathy" in his poetic work. Declaring early on in "Song of Myself" that "I am he attesting sympathy," Whitman's poetic persona becomes a strong advocate for sympathy, asserting that "whoever walks a furlong without sympathy walks to his own funeral drest in his shroud" (LGVar., 1:79). While he also explicitly agreed that Christians had an obligation to sympathize with criminals, and, like Chapin, attempted to school his readers as to the benefits of this interaction for both the objects and subjects of sympathy, Whitman's poetic depiction of sympathy does not deny the challenges involved in sympathetic identification nor present it as an uncomplicated process. In fact he depicts it as a quite difficult struggle, perhaps mostly in a psychological sense, that demands strength and determination from the sympathizer.

The section of "Song of Myself," running from Section 33 through 38 , is perhaps the crucial depiction of the process of sympathetic identification in his poetry. In Section 37 Whitman's persona describes himself as "possess'd," embodying "all presences outlaw'd or suffering," seeing himself "in prison shaped like another man," and feeling "the dull unintermitted pain" (LGVar., 1:59). In just these three lines, we have a perfect example of Whitman's portrayal of the complex process of sympathetic identification, a process depicted as being composed of at least two very different dynamics. Whitman's speaker begins by asserting his "possession" by outlaw and suffering others, which seems to place the agency with those who have "possessed" him. This "possession" leads to his "embodiment" of their presences. As they have claimed control over his body, they will now use him as a medium to speak (in a similar sense to his assertion in Section 24 that the "voices of the interminable generations of prisoners" can be heard "through me"). While this initially appears to be exclusively a passive process on the speaker's part, perhaps requiring only a willingness to open himself 
up to these other presences or voices, the second dynamic requires more active participation - an act of imagination - from him. In this dynamic, he sees himself "in prison shaped like another man" and feels that man's "dull unintermitted pain." Here, Whitman's speaker can imagine himself in the place of imprisoned others and achieves sympathy for them by feeling their pain. He expands his description of this process in the next few lines, as he "becomes" different convicts or joins them in their suffering: "For me the keepers of convicts shoulder their carbines and keep watch, / It is I let out in the morning and barr'd at night. // Not a mutineer walks handcuff'd to jail but I am handcuff'd to him and walk by his side, / [ . . . // Not a youngster is taken for larceny but I go up too, and am tried and sentenced" (59). The section closes with his sympathetic identification with a dying cholera patient ("I also lie at the last gasp, / My face is ash-color'd, my sinews gnarl, away from me people retreat") and a beggar ("I project my hat, sit shame-faced, and beg") (59).

In the 1855 version of "Song of Myself," this section begins differently with a passage that was deleted from subsequent versions, but that can be very useful in developing our understanding of the nature of the sympathetic identification occurring at this point in the poem. Notably, the speaker begins by evoking "O Christ!," suggesting that his Christianity allows this sympathy to happen, and then describes the "fit" that is "mastering" him. This fit allows him to suffer through a number of moments of American punishment: "the rebel . . . gaily adjusting his throat to the rope-noose," "the savage at the stump, his eye-sockets empty, his mouth spirting whoops and defiance," and "the Brooklyn boy . . . look[ing] down the shores of the Wallabout and remember[ing] the prison ships" (LGVar., 1:58n). In reference to these figures, he notes, "These become mine and me every one, and they are but little, / I become as much more as I like" (58n). Again, the speaker asserts that he "becomes" these figures. This is consistent with the dynamic guiding the entire section of Leaves of Grass that begins in Section 33, wherein he identifies with a variety of suffering people, including a woman being told of her husband's death, an accused woman burned as a witch, a "hounded slave," a "mash'd fireman," and the "four hundred and twelve young men" who died in a conflict with Mexican forces (51-54). He explains his relationship to these figures: "I do not ask the wounded person how he feels, I myself become the wounded person" (52). It is interesting, though, that in the original opening lines of Section 37 he characterizes this "becoming" as a "fit" that "masters" him, suggesting that he is not in control of it, but that this sympathy is something that floods into him because he is receptive to it. 
The initial invocation of Christ in these lines indicates that Whitman characterized the process of sympathetic identification, as the anti-gallows ministers did, as a Christian one, as the proper activity of true followers of Christ's teachings, a characterization that he would develop further later in this sequence. Yet even with this notion that sympathy and Christianity are closely associated, the persona of "Song of Myself" resists a whole-hearted embrace of sympathy here. The identification of Whitman's persona with "all presences outlaw'd or suffering," of "seeing myself in prison," leads him to a moment of crisis. The feeling of all this pain of others becomes too much for him. He begins Section 38 proclaiming, "Enough! enough! enough! / Somehow I have been stunn'd. Stand back! / Give me a little time beyond my cuff'd head, slumbers, dreams, gaping, / I discover myself on the verge of a usual mistake" (LGVar., 1:59-60). Numerous readings of the poem offer explanations for what is going on here in terms of the persona's experience of sympathy. For instance, Stephen Black explains that "the identification" he has achieved "carries with it the burden of the other man's suffering and pain" (Black, 95). And Thomas Couser, describing the threat that this process poses to the speaker, claims that his "unrestrained identification with others has nearly obliterated his sense of himself." 32 While the sympathetic persona is likely threatened in multiple ways, Whitman's language emphasizes the suffering one takes on as one attempts to feel another's pain (readers might think of Eva in Stowe's Uncle Tom's Cabin for a parallel, as she physically weakens when the suffering of the slaves "sunk into [her] heart"). ${ }^{33}$ Whitman's persona is "stunn'd," has his head "cuff'd," and is left "gaping" because of all of the sympathy he has expended. This passage of the suffering sympathetic subjects could serve as a good response to criticism by Kristin Boudreau, who views in this sequence of the poem "Whitman's pleasure in sympathy." As evidence of the pleasure Whitman takes in sympathy, she cites the line from Section 33: "All this I swallow, it tastes good, I like it well" (Boudreau, 86). If there is pleasure in this sequence, it is certainly counterbalanced and even outweighed by the overwhelming burden that the sympathetic subject takes on.

In response to this consequence of sympathy, Whitman's persona approaches "the verge of a usual mistake" and begs for distance ("Stand back!") and "a little time." He wishes "[t] hat I could forget the mockers and insults! / That I could forget the trickling tears and the blows of the bludgeons and hammers!" (LGVar., 1:60). This "mistake" here seems to be the attempt to flee from his previous sympathy, to forget the suffering he has seen and felt. Some critics of the poem reinforce this perception. Joel Belson, for example, states that "the mistake of which Whitman accuses himself is his momentary withdrawal from the relation 
of empathy which he has established." He explains that the mistake is "usual" in "the sense that it is common or human." ${ }^{34}$ That is, human beings tend to resist sympathy if the price, emotionally or spiritually, is seen as too high. Sholom Kahn agrees, asserting that "the 'mistake' is one of separation, emotional distance and failure of sympathy." 35 In line 965 of "Song of Myself," Whitman's persona wishes "that I could look with a separate look on my own crucifixion and bloody crowning" (60). This line suggests two different reactions on the part of the persona. First, it suggests that he desires to be concerned only with his own suffering rather than anyone else's (including perhaps Christ's, implying an impulse to reject "Christian sympathy"). While this wish to ignore the suffering of others so that he will not have to feel another's pain is "usual," in that it is an understandable human response, it is also, as Whitman notes, a "mistake." Second, that the speaker's own suffering is described in Christian terms serves as a reminder that he too should be crucified in the way that Christ was (that is, he should, like Christ, be willing to suffer greatly for others). His hesitation to "look on" or imagine another's suffering is what the proponents of sympathy for criminals were trying to combat in their pleas to their readers, especially their Christian readers, to "Feel for him, then, as Christ would feel" and to "Restrain not your sympathies" (J. M. M., 160).

It is important then that Whitman in this moment of crisis evokes the crucifixion of Christ, notably the best-known incident of capital punishment in Western culture. In this passage, wherein critics have seen him "deliberately compar[ing] himself with the crucified and resurrected Christ," Whitman's persona pales in comparison. ${ }^{36}$ As he prefers to think only about his "own crucifixion" in exclusion of others' suffering, a self-interested move, he implicitly contrasts this feeling of self-protection with the motives of Christ, which were of self-sacrifice and sympathy for everyone else in the world. In Christ's crucifixion, he joins the condemned criminals in their suffering, selflessly following divine dictate. This comparison provides a corrective model for those who would rather ignore the suffering of others, including condemned criminals, and the pain they endure. As Belson notes, when the poem's persona expresses "his feeling of identification with Christ," it is this identification that "marks the moment of the redemption of his spirit, of its revitalization" (Belson, 64). After this crisis, what Kahn labels "the most important climax in the poem" (67), the narrator says, "I remember now, / I resume the overstaid fraction, / . . . // I troop forth replenish'd with supreme power" (LGVar., 1:60). The identification with Christ is the key to his marching on, to his resisting the impulse to withdraw into self-protection, and to continuing his sympathetic identification with suffering. 
The meaning of the "overstaid fraction" has puzzled many critics, though a variety of useful readings have been proposed, including James Miller's assertion that it is "the complete insight brought by union with the Transcendent, . . . by outright identification of self with Christ." 37 Betsy Erkkila proposes that "it is the 'overstaid fraction' of Christ as a living power existing within himself as part of an eternal present."38 These are solid readings of the phrase as it suggests the part (or "fraction") of Christ and his sacrifice that remains ("overstaid") after the crucifixion. In some sense, the idea expressed by Whitman here echoes the "Christ within" each Christian that anti-gallows minister Samuel Brimblecom asserted was the source of the sympathy that people of the Christian faith feel for criminals (22). If we see Section 38 of "Song of Myself" as Whitman's dramatization of an individual's feelings of sympathy and resistance to its implications, we should also read this section as illustrating the persona's eventual choice to sympathize, to follow Christ's example, rather than to look only at his "own crucifixion." The consequence is that he avoids the isolation that comes from the fearful stance of self-preservation and resistance of sympathy. Instead, the persona is now "replenish'd with supreme power, one of an average unending procession," with the ability to "pass all boundary lines" (LGVar., 1:60). This unity with an "unending procession" parallels the potential for progress portrayed by Chapin, which begins with the individual choice to practice "the great law of love, of Christian sympathy" and then leads all "humanity to rise and shine in the splendor of a new day, and the beauty of a new power"(Chapin, 89).

For Whitman, as for many of the opponents of capital punishment, encouraging sympathy for the criminal was a key element in creating a public outcry that would cause legislators to abolish the gallows. Much of his writing schools the reader in the need for sympathy and even models the process as he identifies sympathetically with the actual murderers described in his prose pieces or the imagined ones in his poetry. While Whitman would not live to see capital punishment abolished, he did attribute the reforms in justice that he did see in his lifetime to an increased sympathy among the American public. As he wrote in 1858, "an increased sensitiveness on the part of the public, toward any useless harshness in the treatment of criminals" had been created by the advocates against the gallows, which had "diffus[ed] more benevolence and sympathy through the public mind, elevating the range of temper and feeling, and reacting in a hundred different modes, indirectly upon the popular taste, and upon criminal law, the doings of Courts and Juries, and the management of Prisons" (UPP, 15-16). While the gallows remained, Whitman celebrated the "increased sensitiveness," "benevolence and sympathy through the public mind" 
as a positive outcome of the reform movement, believing like Chapin, that increased sympathy is fundamental to all social progress.

As I conclude, I would like to grant merit to Stephen Black's pronouncement that "the poet is more pre-occupied with his own sympathies" than he is with the circumstances of those toward whom he is sympathetic, whether they be slaves, prostitutes, or convicted murderers (Black, 93). That is, unlike some of his anti-gallows contemporaries, Whitman seems to see sympathy as a valuable end in itself, even if it does not immediately achieve progressive reforms, including the abolition of capital punishment. However, I disagree with Black's implication that it is only "his own sympathies" that concern Whitman because he certainly seems to be modeling the process of sympathy for his readers to follow as well. As he noted in "By Blue Ontario's Shore," part of his project as poet is to "Produce great Persons," believing that "the rest follows" (LGVar., 1:192). Sympathy would definitely be part of the make-up of Whitman's conception of "great Persons," as he believes that one can only lead a full life if one is open to sympathetic identification. If this is the case, Whitman would not be alone among the anti-gallows voices in his assertion that sympathy might be an end in itself and beneficial to the sympathetic. As we saw earlier, E. H. Chapin claimed that by "cherishing the spirit of Christian sympathy, . . . a tide of sympathy shall flow out from heart to heart, that will finally meliorate the condition of our race." While he does not clarify when this amelioration will occur, he does acknowledge the benefit that the sympathizer will feel in the meantime by claiming that "at least in ourselves will be a rich reward" (89). While Whitman would agree that there is "rich reward" for the sympathetic subject, he also suggests that progress, including the end of capital executions, would eventually come from a widespread embrace of sympathy.

Ohio University

\section{NOTES}

1 Whitman's own comments late in his life have contributed to this dismissive attitude, as he implied that he saw his early anti-gallows activism, like his support of other reforms, as something that he had put behind him. For example, in his introductory remarks to Collect (1891), he seemed to apologize for the section, "Pieces in Early Youth," which collected works from the 1840s, by explaining that "I was then quite an 'abolitionist' and advocate of the 'temperance' and 'anti-capital-punishment' causes." See Walt Whitman, Complete Poetry and Collected Prose (New York: Library of America, 1982), 927. Additionally, he commented to Horace Traubel that he was "in early life very bigoted in my anti-slavery, anti-capital-punishment and so on," With Walt Whitman in Camden, vol. 1 (New York: Mitchell Kennerley, 1915), 193. 
2 To date, the most thorough discussions of Whitman's involvement in the antigallows movement have occurred in Thomas Brasher, Whitman as Editor of the Brooklyn Daily Eagle (Detroit: Wayne State University Press, 1970), 150-154, and Joseph Rubin, The Historic Whitman (University Park: Pennsylvania State University Press, 1973), 116-125. David Brion Davis's very important essay on the subject of anti-gallows reform, "The Movement to Abolish Capital Punishment in America, 1787-1861," includes a quick reference to one of Whitman's anti-gallows prose pieces; American Historical Review 63 (October 1957), 30. And, more recently, John Cyril Barton has briefly examined some of Whitman's prose writing against capital punishment in "The Anti-Gallows Movement in Antebellum America," REAL: Yearbook of Research in English and American Literature 22 (2006), 170-173. None of these scholars has made significant connections between Whitman's 1840 s reform work and his later poetry.

3 Michael Moon, Disseminating Whitman: Revision and Corporeality in Leaves of Grass (Cambridge: Harvard University Press, 1991), 3.

4 Katherine Molinoff. An Unpublished Whitman Manuscript: The Record Book of the Smithtown Debating Society, 1837-1838 (Brooklyn: Comet Press, 1941), 5.

5 For a discussion of the Democratic Review's campaign against the gallows, see Paul Christian Jones, "The Politics of Poetry: The Democratic Review and the Gallows Verse of William Wordsworth and John Greenleaf Whittier," American Periodicals 17 (2007), 1-25. For background on the organized opposition to capital punishment in $1840 \mathrm{~s}$ New York, see Philip Mackey, Hanging in the Balance: The Anti-Capital Punishment Movement in New York State, 1776-1861 (New York: Garland, 1982) and Louis Masur, Rites of Execution: Capital Punishment and the Transformation of American Culture, 17761865 (New York: Oxford University Press, 1989).

6 "Capital Punishment," Uncollected Poetry and Prose of Walt Whitman, ed. Emory Holloway (New York: Peter Smith, 1932), 2:15-16. Hereafter, UPP.

7 "Ourselves and the 'Eagle," fournalism, 1:392. This essay will make much use of Walt Whitman, The fournalism, 2 vols., ed. Herbert Bergman (New York: Peter Lang, 1998, 2004). Subsequent references will be noted in the text as fourn and cited with volume and page numbers. These volumes include dozens of anti-death penalty pieces. Yet, it is likely that even in the years covered by these volumes, 1834-1848, there are additional writings by Whitman about the gallows. Jerome Loving, in a review of the second volume, includes a list of pieces that he and others have attributed to Whitman but which were omitted without explanation from Bergman's volumes. These include a number of pieces from the Eagle - such as "Capital Punishment" and "What the Hanging Laws Have Done" - that address the issue of the death penalty. See Loving's review of The fournalism, Vol. 2, in Walt Whitman Quarterly Review 22 (Summer 2004), 34-35. Additionally, William White's Walt Whitman's fournalism: A Bibliography (Detroit: Wayne State University Press, 1969) illustrates that Whitman continued to write about capital punishment throughout the 1850 s, primarily in pieces for the Brooklyn Daily Times.

8 David Ray Papke, Framing the Criminal: Crime, Cultural Work and the Loss of Critical Perspective, 1830-1900 (Hamden, CT: Archon, 1987). 
9 For pieces expressing Whitman's concern about the conviction and execution of innocents, see fourn 1:160-161 and 2:316. For his arguments that the death penalty does not deter crime, see fourn 1:353 and 477. For his concerns about the detrimental effects of hanging on the spectators, see fourn 1:457-458 and 2:307. And, for his claims that guilty people are not being convicted because of the death penalty, see Fourn 1:317, 336, 353, and 475.

10 Quotations from Whitman's poetry are from Leaves of Grass: A Textual Variorum of the Printed Poems, 3 vols., ed. Sculley Bradley, Harold Blodgett, Arthur Golden, and William White (New York: New York University Press, 1980). Hereafter, LGVar., followed by volume and page number.

11 Philip Fisher, Hard Facts: Setting and Form in the American Novel (New York: Oxford University Press, 1985), 99.

12 "Freeman the Negro Murderer," National Police Gazette (April 11, 1846), 268.

13 "More Disclosures of the Van Ness Massacre," National Police Gazette (March 28, 1846), 243.

14 D.H., "The Awful Tragedy in Cayuga," Harbinger (April 4, 1846), 272.

15 Leonard Bacon, "Shall Punishment be Abolished?," New Englander 4 (October 1846), 565.

16 Joseph P. Thompson, The Right and Necessity of Inflicting the Punishment of Death for Murder (New Haven, CT: J. M. Patten, 1842), 51.

17 George B. Cheever, Punishment by Death: Its Authority and Expediency (New York: M. W. Dodd, 1842), 149.

18 William N. Barber, Capital Punishment. A Sermon, Preached in the Universalist Church, Swanzey, N. H. Fuly 4, 1841 (Brattleboro, VT: Wm. E. Ryther, 1841), 10.

19 E. H. Chapin, Three Discourses upon Capital Punishment (Boston: Trumpet Office, 1843), 70-71.

20 "Debates at the Convention on Capital Punishment," Hangman (February 5, 1845), 22.

21 G. W. Quinby, The Gallows, The Prison, and the Poor-House. A Plea for Humanity; Showing the Demands of Christianity in Behalf of the Criminal and Perishing Classes (Cincinnati: G. W. Quinby, 1856), 49.

22 J. M. M., "Compassion for the Sinful," Monthly Miscellany of Religion and Letters 7 (September 1842), 160.

23 David Reynolds has classified Whitman's religion as "ecumenical," as he "embrac[es] many different religions without lending absolute credence to any single 
one." He frequently "attended services in various denominations," from evangelical Methodist revivals, rigidly Calvinist Dutch Reformed services, and Quaker meetings. Whitman expressed his criticism for organized religion in his 1856 letter to Ralph Waldo Emerson: "The churches are one vast lie; the people do not believe them, and they do not believe themselves; the priests are continually telling what they know well enough is not so, and keeping back what they know is so. The spectacle is a pitiful one." See Walt Whitman's America: A Cultural Biography (New York: Knopf, 1995), 36, 39, 238.

24 Elsewhere in this piece, he names some of these ministers, as he calls "the Cheevers and Lewises . . . ye pleaders for the dungeon, the fetter, and the gallows" and challenges them to respond to statistics that crime has decreased in Great Britain with greater restrictions on capital punishment (Fourn, 2:43). He refers here to George Cheever and Tayler Lewis, who had just published A Defence of Capital Punishment (New York: Wiley and Putnam, 1846). Whitman had previously mocked Lewis's positions in "T. L.' on Hanging" (Fourn, 1:319-320); he criticized Cheever elsewhere for his "sophisms . . . in behalf of the gallows" (Fourn, 2:307) and for advocating that "Heaven thirsts for blood" (Fourn, 1:439).

25 Glenn Hendler, Public Sentiments: Structures of Feeling in Nineteenth-Century American Literature (Chapel Hill: University of North Carolina Press, 2001), 3-4.

26 Karen Sánchez-Eppler, Touching Liberty: Abolition, Feminism, and the Politics of the Body (Berkeley: University of California Press, 1993), 52, 68.

27 Kristin Boudreau, Sympathy in American Literature: American Sentiments from Fefferson to the Fameses (Gainesville: University Press of Florida, 2002), 12.

28 All seven editions of Leaves of Grass in transcription and facsimile are also available at the Walt Whitman Archive (www.whitmanarchive.org).

29 Denis Donoghue, Connoisseurs of Chaos: Ideas of Order in Modern American Poetry, $2^{\text {nd }}$ ed. (New York: Columbia University Press, 1984), 29.

30 Stephen Black, Whitman's fourneys into Chaos: A Psychoanalytic Study of the Poetic Process (Princeton: Princeton University Press, 1975), 93.

31 E. H. Chapin, “Christian Sympathy," Symbol and Odd Fellow's Magazine 3 (April 1844), 89.

32 G. Thomas Couser, American Autobiography - the Prophetic Mode (Amherst: University of Massachusetts Press, 1979), 91.

33 Harriet Beecher Stowe, Uncle Tom's Cabin (1852; rpt. New York: W. W. Norton, 1994), 204.

34 Joel Jay Belson, "Whitman's 'Overstaid Fraction," Walt Whitman Review 17 (June 1971), 64. 
35 Sholom Kahn, "Whitman's 'Overstaid Fraction' Again," Walt Whitman Review 20 (June 1974), 71.

36 J. Middleton Murry, "Walt Whitman: The Prophet of Democracy," Leaves of Grass One Hundred Years After, ed. Milton Hindus (Stanford: Stanford University Press, 1955), 137. This passage of "Song of Myself" is not the only place where this comparison occurs. In "To Him That was Crucified," the persona parallels himself to Christ and suggests that they are doing the same work. And in "Chanting the Square Deific," as the speaker compares himself to a number of divine figures, including "Lord Christ," and notes "Many times have I been rejected, taunted, put in prison, and crucified, and many times shall be again" (LGVar., 2:544).

37 James E. Miller, Jr., A Critical Guide to Leaves of Grass (Chicago: University of Chicago Press, 1957), 25.

38 Betsy Erkkila, Whitman the Political Poet (New York: Oxford University Press, 1989), 112. 